\title{
АНАЛІЗ ПОШИРЕНОСТІ ЗЛОЯКІСНИХ ПУХЛИН ТА ПОЛІПІВ ТОВСТОЇ ТА ПРЯМОЇ КИШОК У СТРУКТУРІ ПРОВЕДЕНИХ ДІАГНОСТИЧНИХ ПРОЦЕДУР КРАЇНИ МАЛЬТА
}

\author{
Н. В. Шандаровська, Н. В. Петренко \\ ДВНЗ «Тернопільський державний медичний університет \\ імені І. Я. Горбачевського МОЗ Украӥни"
}

У статті проаналізовано поширеність колоректального раку та доброякісних новоутворень товстої та прямої кишок у структурі проведених діагностичних ендоскопічних процедур країни Мальта.

\section{ANALYSIS OF THE INCIDENCE OF MALIGNANT TUMOURS AND POLYPS OF THE COLON AND RECTUM WITHIN DIAGNOSTIC PROCEDURES PERFORMED IN MALTA}

\author{
N. V. Shandarovska, N. V. Petrenko
}

\section{Horbachevsky Ternopil State Medical University}

The article analyses the incidence of malignant and benign neoplasms of the colon and rectum within the structure of diagnostic endoscopic procedures performed in Malta.

Вступ. У світі колоректальний рак (КРР) $є$ однією з найпоширеніших нозологічних форм злоякісних новоутворень, частота якої має тенденцію до неухильного зростання. За даними Міжнародного агентства з дослідження раку Всесвітньої організації охорони здоров'я, кожного року реєструють 1360000 нових випадків раку товстої кишки [1]. За поширеністю серед онкологічних захворювань в світі ця патологія займає третє місце, за смертністю - четверте. Майже 55 \% випадків захворювання припадає на більш розвинуті регіони [2]. Зокрема, в країні Мальта КРР за рівнем виявлення та смертності вийшов на друге місце, поступаючись лише раку молочної залози за рівнем виявлення та раку легень - за смертністю [3].

Для боротьби з цим захворюванням ефективними методами $\epsilon$, безумовно, усунення факторів ризику та скринінг. Ефективність профілактичних оглядівзалежить, головним чином, від рівня участі в ній громадян, а це, в свою чергу, корелює з рівнем обізнаності щодо небезпеки КРР та можливістю ефективної його профілактики [4].

Мета дослідження: визначити частоту виявлення доброякісних та злоякісних новоутворень товстої та

(c) Н. В. Шандаровська, Н. В. Петренко, 2018 прямої кишок при проведенні колоноскопічних досліджень в країні Мальта.

Основна частина. Ми провели ретроспективний аналіз результатів патогістологічних досліджень, які виконали в ендоскопічному відділенні лікарні державного рівня Mater Dei Hospital (MDH) країни Мальти.

Дослідження проводили за медичними показаннями та за скринінговою програмою шляхом гнучкої сигмоскопії та колоноскопії. Для аналізу було взято 378 результатів дослідження, проведених у травні 2017 р. Поширеність доброякісних та злоякісних новоутворень товстої та прямої кишок визначали за частотою виявлення патологічних змін залежно від соціально-біологічних особливостей обстежених та причин звернення.

У травні 2017 р. в ендоскопічному відділенні MDH проведено 378 колоноскопій та гнучких сигмоскопій.

Серед пацієнтів, які пройшли обстеження, було 158 (41,8 \%) чоловіків та 220 (58,2 \%) жінок. Середній вік обстежених становив $(56,8 \pm 2,3)$ року. Вікова структура обстежених пацієнтів наведена на рисунку 1.

Як видно з рисунка 1, частота проведення обстежень прямої та товстої кишок починає збільшуватись 
після 45 років, досягаючи свого максимуму в 61-65 років. Ця тенденція не відрізнялася у чоловіків та жінок.
Структура причин, із приводу яких проведено колоноскопічне дослідження наведена на рисунку 2.

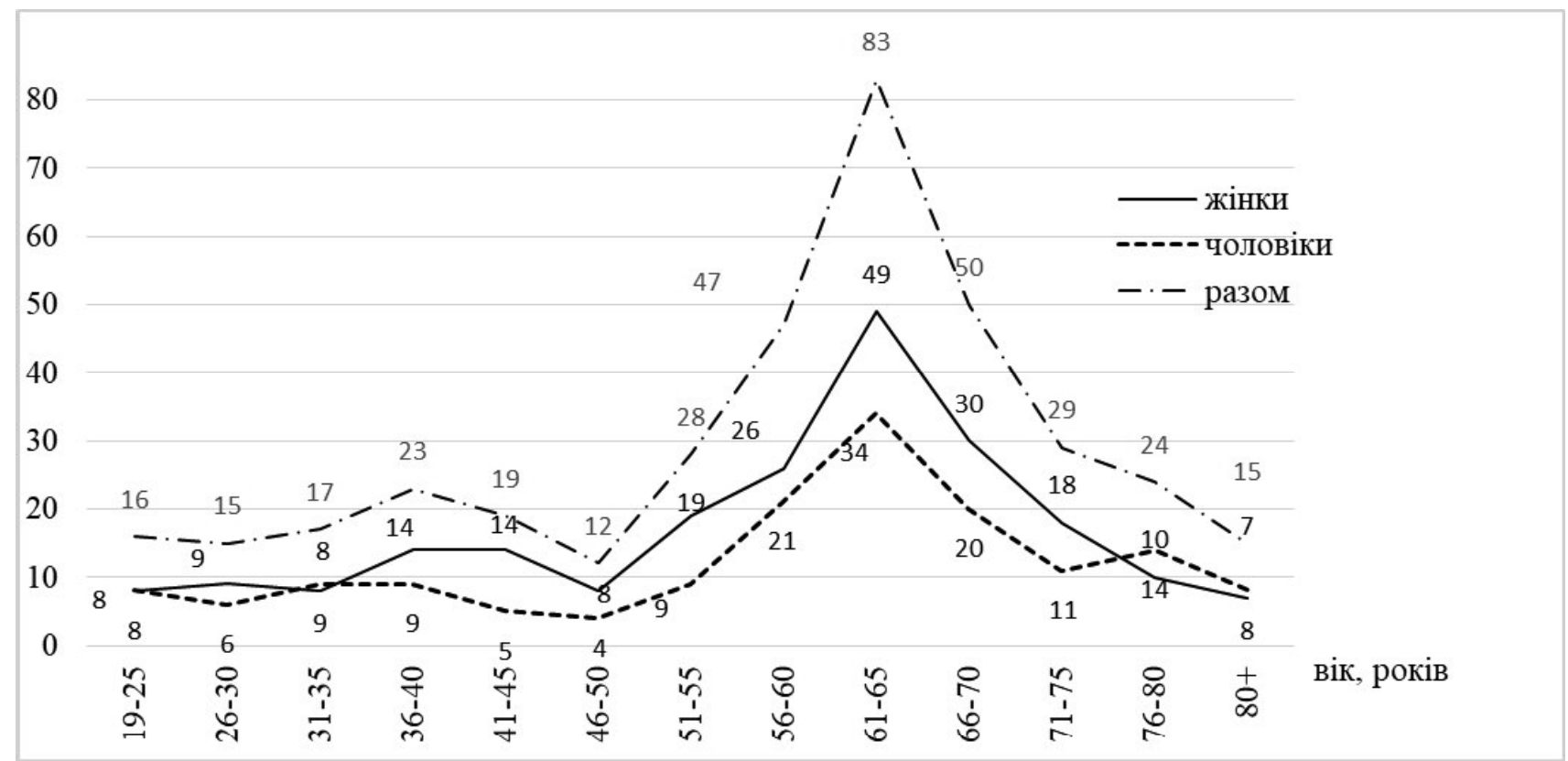

Pис. 1. Вікова структура обстежених пацієнтів.

Регулярне спостереження при хронічних запальних захворюваннях кишечника та після видалення новоутворень $89(24 \%)$

Скринінг

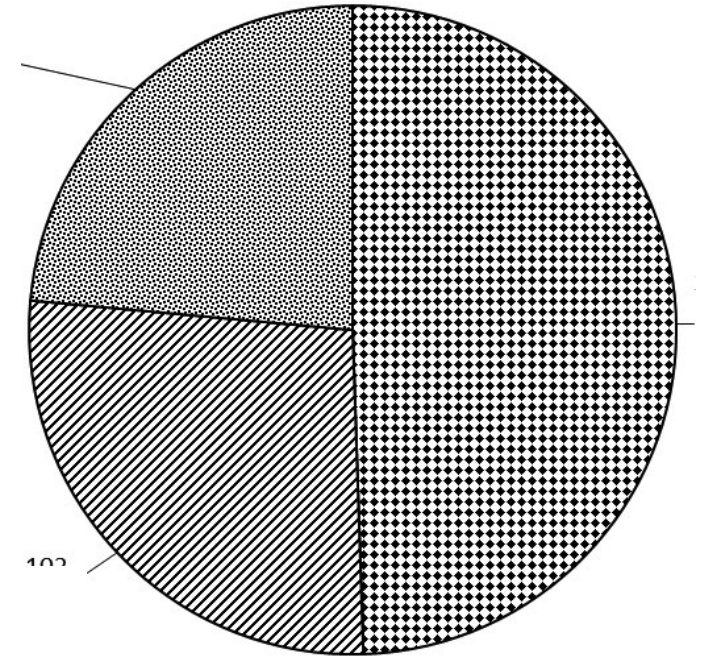

За медичними показаннями $187(49 \%)$ $102(27 \%)$

Рис. 2. Структура показань, з приводу яких проводили колоноскопічне дослідження.

Як видно з рисунка 2, у 187 (49 \%) пацієнтів дослідження проводили за медичними показаннями, в 102 (27\%) - як скринінгове дослідження при обтяженому сімейному анамнезі щодо злоякісних пухлин кишечника, у 50 (13\%) для контролю виліковності після видалення новоутворень (поліпів, пухлин), ау 39 (11\%)при хронічних запальних захворюваннях кишечника.

Ми встановили певні гендерні відмінності у проходженні колоноскопічного дослідження. Як показало наше дослідження (рис. 3), частота проведення дослідження з приводу медичних показань була на
12 \% більшою серед жінок, ніж чоловіків, з приводу динамічного спостереження після видалення пухлини чи лікування запального захворювання на 10 \%, за скринінговою програмою - на 11 \%, що свідчить про більш уважне ставлення жінок до стану здоров'я порівняно з чоловіками.

У 187 (49 \%) пацієнтів колоноскопічне дослідження проводили у зв'язку з наявністю скарг із боку функціонування шлунково-кишкового тракту. Структура медичних показань для проведення колоноскопічного дослідження наведена на рисунку 4. 


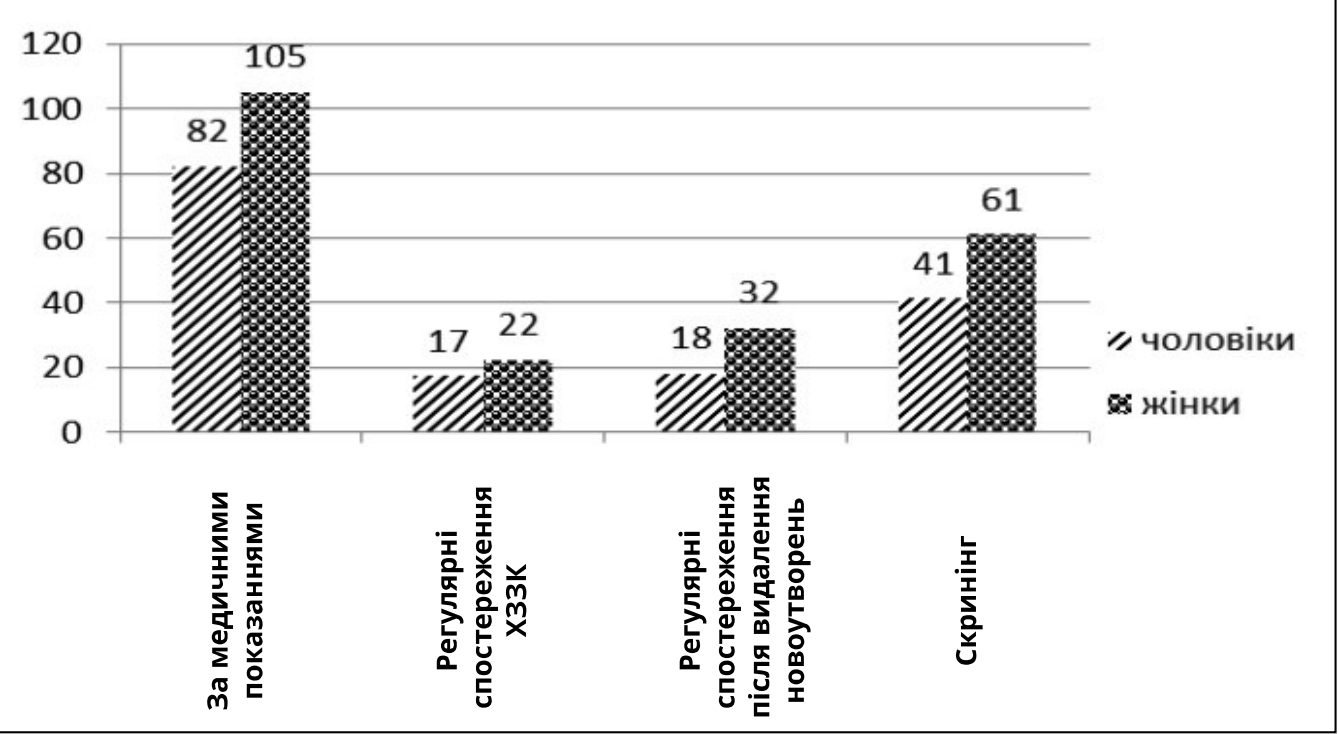

Рис. 3. Частота участі у колоноскопічних обстеженнях залежно від статі.

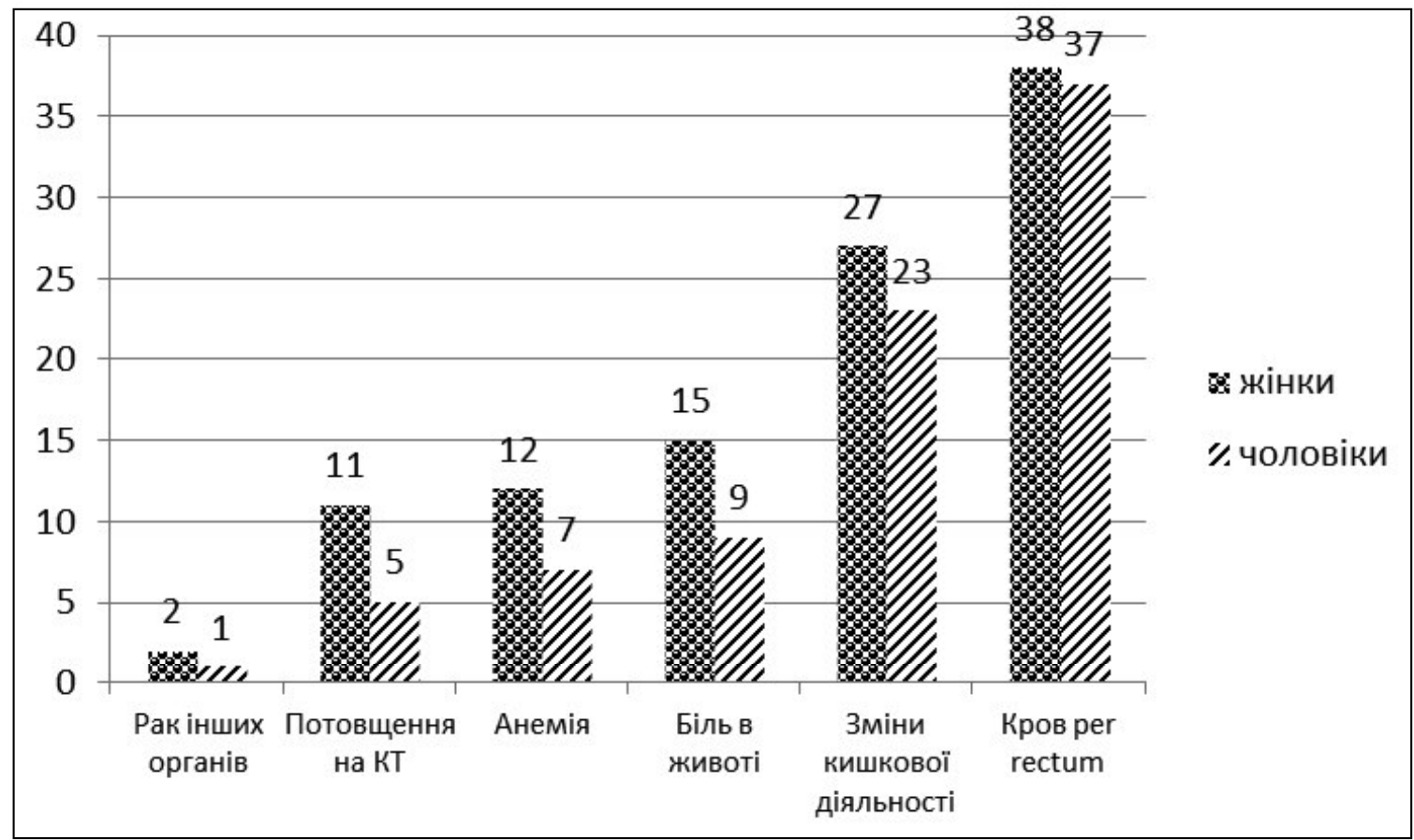

PUс. 4. Структура медичних показань, за якими проводили колоноскопічне дослідження залежно від статевої приналежності.

Встановлено, що у 75 (40 \%) пацієнтів дослідження проводили з приводу появи видимої крові в калі, у 50 (27\%) - змін кишкової діяльності (закрепи, проноси, метеоризм), у 24 (13\%) - болю в животі.

Як додатковий метод дослідження при діагностичному пошуку в 19 (10\%) пацієнтів колоноскопія проведена при анемії, у 16 (8,4%) - при підозрі на рак товстої кишки (зміни на комп'ютерній томограмі), у 3 (1,6 \%) - при злоякісних пухлинах інших локалізацій. Варто відзначити, що жінки частіше проходили це дослідження, ніж чоловіки.

Аналізуючи отримані результати встановлено, що доброякісні зміни були у 220 (59 \%) обстежених, нормальна макроскопічна структура кишечника у 145 (38\%), злоякісні новоутворення - у 13 (3 \%). Структуру виявлених змін наведено на рисунку 5. 


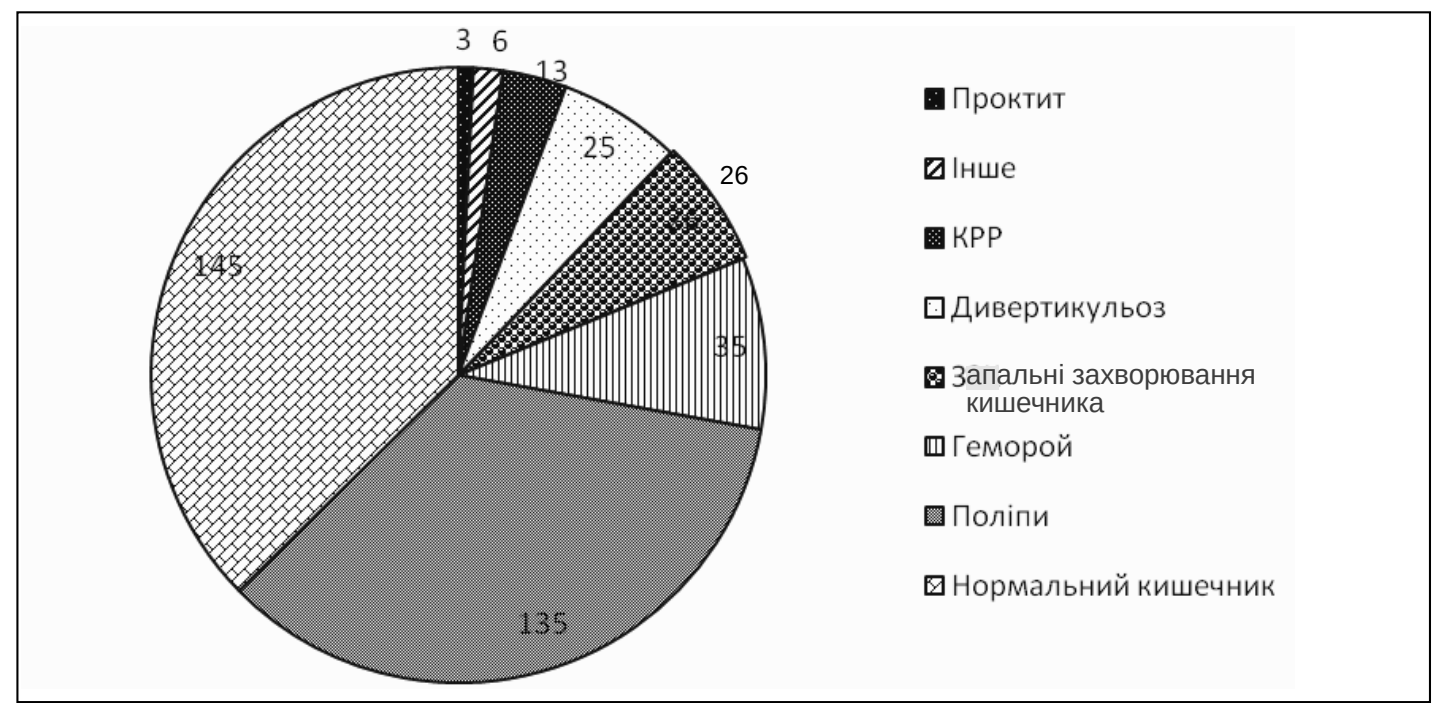

Рис. 5. Результати колоноскопічних досліджень.

Як видно з рисунка 5, серед доброякісних новоутворень поліпи кишечника мали місце у 135 (36 \%) пацієнтів, геморой - 35 (9,2 \%), запальні захворювання кишечника (виразковий коліт, хвороба Крона та інші) у 26 (6,8 \%), дивертикульоз - в 25 (6,6 \%), проктит - у
3 (0,8 \%), тріщина прямої кишки - в 3 (0,8 \%), звуження кишечника (стриктура) - у 3 (0,8 \%).

Ми провели аналіз виявлених злоякісних та доброякісних новоутворень залежно від віку та статі, частота яких наведена на рисунках 6 і 7.

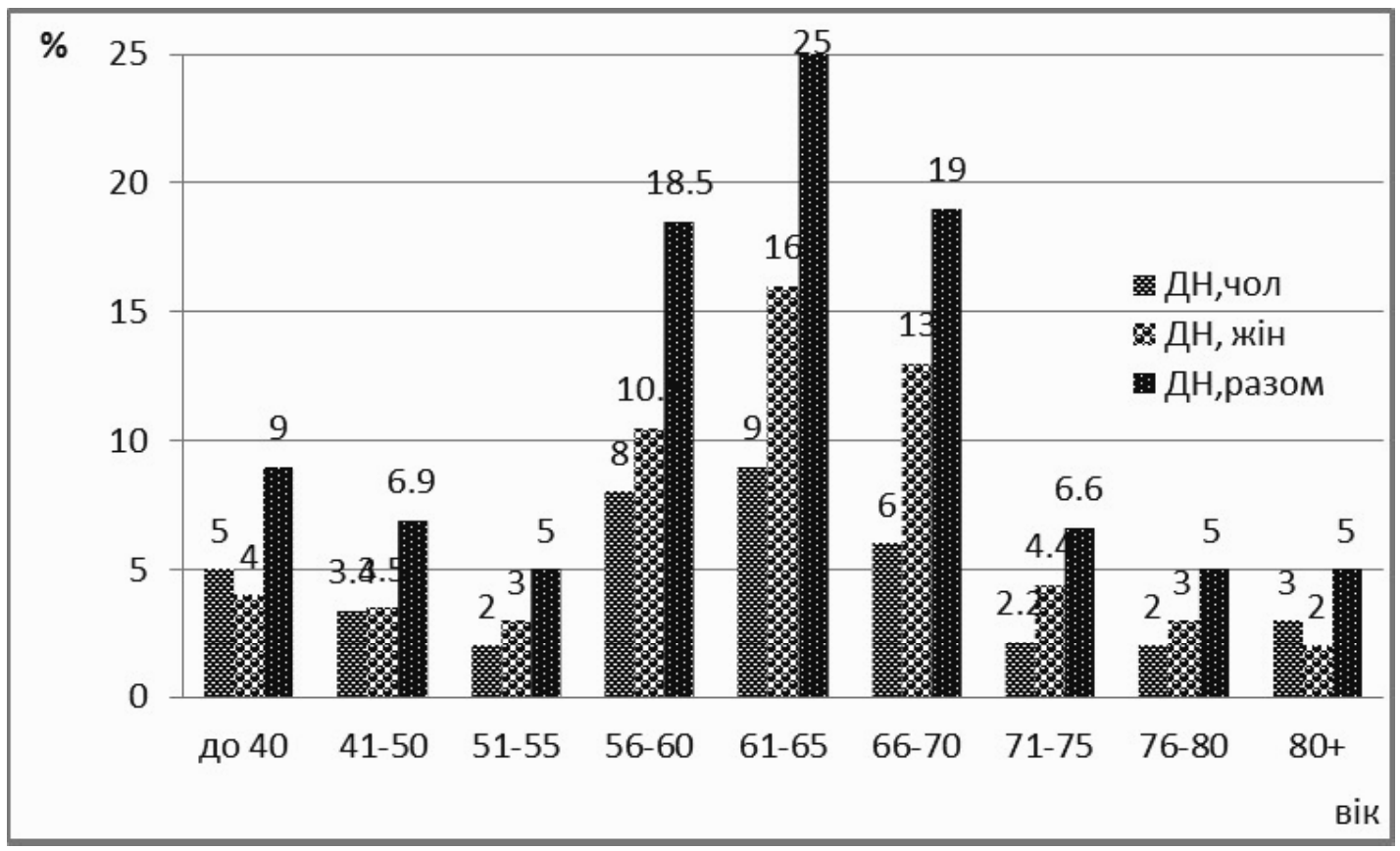

Рис. 6. Вікова структура частоти виявлених доброякісних новоутворень залежно від статі.

Як видно з рисунка 6, частота виявлення доброякісних новоутворень різко зростає у віці 56-70 років, досягаючи максимуму в 61-65 років. Варто відзначити, що поліпи також виявляли у досить молодих людей до 40 років, причому 1,3-1,8 раза частіше, ніж у віці 41-50 та 51-50 років відповідно.

Злоякісні новоутворення товстої та прямої кишок виявлені у 6 (3,79 \%) чоловіків та 7 (3,18\%) жінок.
Середній вік цих пацієнтів становив $(76,5 \pm 7,2)$ року. Як видно з рисунка 7, злоякісні новоутворення товстої та прямої кишок починають виявляти у віці після 56 років, вони досягають максимуму в 76-80 років. Варто відзначити, що у жінок злоякісні новоутворення кишечника найчастіше діагностують у віці 61-65 років, тоді як у чоловіків - у віці 76-80 років. 


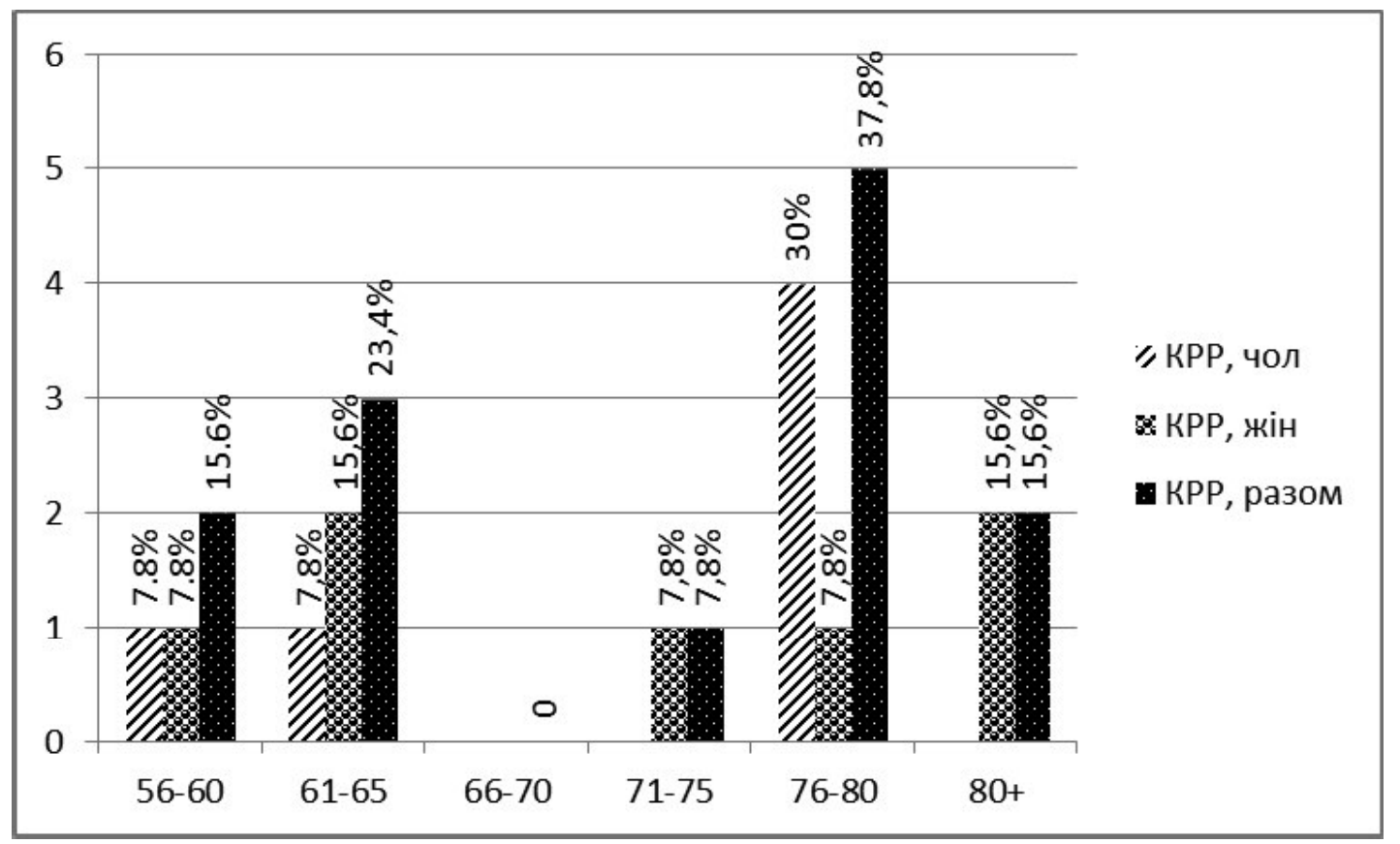

Рис. 7. Вікова структура частоти виявлених злоякісних новоутворень залежно від статі.

Висновки. 1. Діагностичні процедури для макроскопічної оцінки слизової оболонки товстої та прямої кишок найчастіше проводили у віці 46-75 років, проте пік їх частоти припадає на вік 61-65 років.

2. Діагностичну колоноскопію та гнучку сигмоскопію проводили через скарги пацієнтів на порушення діяльності кишечника (49 \%) як скринінгове обстеження (27 \%) та для динамічного спостереження за станом слизової кишечника після терапевтичного чи хірургічного лікування (24 \%).

3. Найпоширенішими проявами дисфункції кишечника, яка турбувала пацієнтів, були поява видимої крові в калі (40 \%), зміни діяльності кишечника (закрепи, проноси, метеоризм) (27 \%), біль в животі (13\%), а у медичних працівників - анемія (10\%), підозра на рак товстої кишки (8,4\%), підозра на злоякісні пухлини інших локалізацій (1,6 \%).

\section{СПИСОК ЛІТЕРАТУРИ}

1. URL : http://gco.iarc.fr

2. Centers for Disease Control and Prevention. National vital statistics system. https://www.cdc.gov/nchs/nvss/ bridged_race/data_documentation.htm. Accessed December 22, 2016

3. Egs : SEER Cancer Statistics Review, 1975-2012 / N. Howlader, A. M. Noone, M. Krapcho [et al.]. - Bethesda,
4. Доброякісні новоутворення кишечника виявляли більше ніж у половини обстежених (59 \%), у віці 56-70 років (63\%), найчастіше це були поліпи (36\%), геморой (9,2 \%), запальні захворювання кишечника (6,8 \%) та дивертикульоз (6,6 \%).

5. Злоякісні новоутворення вперше були виявлені у 13 (3 \%) пацієнтів, у віці $(76,5 \pm 7,2)$ року, причому найчастіше виявляли у віковій групі 76-80 років.

6. Більша кількість пацієнтів, які пройшли колоноскопічне дослідження як за скринінговою програмою, так і за регулярними плановими обстеженнями, були жіночої статі, що свідчить про більш свідому оцінку наявних ризиків захворюваності на колоректальний рак та більш відповідальне ставлення до стану свого здоров'я.

MD: National Cancer Institute; 2015. http://seer.cancer.gov/ csr/1975_2012/. Accessed June 10, 2017.

4. Bibbins-Domingo K. US Preventive Services Task Force Screening for Colorectal Cancer: US Preventive Services Task Force Recommendation Statement / K. Bibbins-Domingo, D. C. Grossman. - JAMA. - 2016. - Vol. 315. - P. 2. - http:// www.aafp.org 